\title{
Male is Feminine under Patriarchal Governments: Male Characters of 1984 by George Orwell
}

\author{
Rania Khelifa Chelihi*, Mohd Nazri Latiff Azmi
}

Faculty of languages and communications, Department of English language, UNISZA, 21300 Kuala Terengganu, Terengganu, Malaysia *Corresponding Author

\begin{abstract}
Feminist criticism studies the ways in which literature enhances the economic, political, social and psychological oppression of women. Patriarchy describes the power relationships between men and women. Although the majority of the existing literature spots the light on the issue of violence against women, violence against men is also a key feature of patriarchy. This paper aims at exploring how patriarchy systems not only oppress women but men also are oppressed in patriarchal societies. With relevance to male characters of Nineteen Eighty-Four, by George Orwell. It is a political satirical dystopian science fiction novel, which has become universally recognized as Orwell's seminal work. The citizens of Oceania in the novel are under complete control of the totalitarian government. This paper will not go through Orwell's characteristics of a totalitarian state, but it is a study of how patriarchy system oppresses Winston; who symbolizes all men in society who are suffering from under patriarchal governments and comes to a conclusion that Winston is feminine in certain cases in his society.
\end{abstract}

Keywords-Patriarchy, oppression, George Orwell, male, feminine.

\section{INTRODUCTION}

Gender roles play a significant role in all of George Orwell's novels. More particularly, in nineteen -EightyFour gender plays into the prosperity of the party, which tries to neutralize the importance of gender. Though the party attempts to make gender irrelevant in its dystopian society. Many feminist critics have strongly criticized Orwell in terms of the sexual-politics and the way how he deals with gender issues in his works, with their argument principally concentrating on the depiction of Julia. Patia Dauphin in "The Orwell Myth", examines most of Orwell's works, streaking both manhood and misogyny themes that can be seen through all of his works. She sees Orwell as anti-feminist because of his disparaging and despising standpoints towards women through his female characters. But she did not take into consideration how he treats male characters in his novels. According to her, Orwell seems to be interested in male power and traditional gender power (Patai, 1984). As a radical feminist, her feminist believes blinded her and made her utterly disregarded the subjection of men by other men who are more privileged, in Oceania's patriarchal society. In our societies, the influence of patriarchy on gender roles are oppressive to all, not only females. But women, genderqueer, transsexual and so on...et al. Because men are seen to be the strongest in societies, no one really thinks that they could be persecuted. However, by recognizing how gender roles constraint women, it is facile to see how gender roles can be equally as constraining to men. Therefore, feminism is not only exclusive on women, but it should be approached as a community effort; so as to frustrate gender standards that limit both genders.

Atwood in her article 'The Handmaid's Tale and Oryx and Crake in context', said that Orwell's novel, 1984 inspired her to write her dystopian novel 'Handmaid's Tale' (2004). She gave credit to 1984, 'particularly the epilogue', she wanted to drift away from a male vision of dystopias, and write dystopia's world from a female perspective, a world "according to Julia" (Atwood, 2004). But her feminist believes, like most feminist scholars and activists, make her "to call attention to male violence against women... [And] choose to portray females as always and only victims" (Hooks, 2000). Atwood ignored in her critical essay that the protagonist Winston Smith suffers from under an authoritarian rule in Oceania. Like all the other members of the party from both genders -male and 
females. Although, it is true that Orwell portrays female characters as flat females, never one can know what is the last name of Julia, though the reader can know much more details about her body; and at the same time the character of Winston is written as a sympathetic character, with his familiar name and identifiable country. We can observe thatSmith, experience the same pain under authoritarian rules, like all the other members of the party from both genders (female and male).

\section{PATRIARCHY HARMS EVERYBODY IN 1984}

1984 is a novel about the protagonist Winston Smith, who is a thirty-nine years old, hard worker in the Ministry of Truth. Winston lives in a prison-likeworld set in the future, which is under the rule of Big Brother. In this world "Always the eyes watching you and the voice enveloping you. Asleep or awake, working or eating, indoors or out of doors, in the bath or in the bed-no escape. Nothing was your own except the few cubic centimeters". The novel opens with the arrival of Winston to his home, it is a flat in 'Victory Mansions' (Orwell 3), a modern but gloomy building with glass entryways, which dates from the thirties (Orwell 22). In its gateway hangs a big poster of a black-mustachioed man- 'one of those pictures which are so contrived that the eyes follow you about when you move' (Orwell 3) _ which reads: 'BIG BROTHER IS WATCHING YOU'. The government placed a telescreen in the flat, a device that no one can turn it off. So, it enables them to control everything happened or said in the flat. The atmosphere of the place seems gloomy in general, conveyed by boiled cabbage smell, just as the cold and boring scene outside, where another poster with the word 'INGSOC' and in the distance, there is a police helicopter that can be seen through the window (Orwell 4).

Winston lives under constant surveillance by the ruling party in the "chief city of Airstrip One, as well as the other citizens; men and women. "Chief city of Airstrip One, itself the third most populous of provinces of Oceania" (Orwell 5). From the first pages of the novel, one can recognize that the Oceania society is a patriarchal one. It is explained by Morrissey that patriarchy is can refer to relations of governance governed by a father (2003). It is a connotation that indicates the relationship between the father and son; therefore the ruler. It likewise alludes to authority and power between an object and subject and subsumes amongst others. Furthermore, the relation could be noticed between an authoritative state and a developing nation, as it could be noticed between two females or two males ...ect(Hooks, 2000; Seaton, 2010). According to this definition of patriarchy, we can say that Big-Brother is the patriarch who oppressed and dominated all the members of the society regardless of their gender. Big-Brother is a fictional character and symbol in the novel. $\mathrm{He}$ is introduced as the face of the Party and symbolizes the ideology that it stands for. The party holds power over society through its constant surveillance and by oppressing its citizens sexually. Besides, Big- Brother is an omniscient being and the embodiment of the surveillance.

"Hierarchy destroys fraternity" states Crick by putting emphasis on the ironic name attributed to the patriarchal power-holder of Oceania, Big Brother (Crick, 2007). The moral value associated with a family member is turned upside down; because, in the novel, the brother of all is "not watching over [them] as a brother should" but is watching over them in a threatening manner (Crick, 2007). His presence is felt literally everywhere as Winston states,

"[o]n each landing, opposite the lift shaft, the poster with the enormous face gazed from the wall. It was one of those pictures which are so contrived that the eyes follow you about when you move. BIG BROTHER IS WATCHING YOU”, the caption beneath it ran" (Orwell 3).

This statement is critical because it indicates how to control elements work within the ruler subject binary in the public sphere intervened through worries over the public sphere. Moreover, this statement is important for us to comprehend patterns of oppression that characterize the privileged and underprivileged. Therefore, the abovementioned statements and others listed below enable the researcher to grasp the dynamics of oppressive practices, frequently featuring an element that has been, now and again, disregarded by most researchers (Akgul, 2017). To this extent, the binary ruler subject can be revealed by analyzing the male characters of 1984 .

Indeed, we cannot deny that Julia is suffering from both oppressive powers at the same time; First, She is mistreated by Winston, he said that he 'hated her because she was young and pretty and sexless because he wanted to go to bed with her and would never do so, because round her sweet supple waist, which seemed to ask to encircle it with your arm, there was only the odious scarlet sash, aggressive symbol of chastity' (Orwell 17). She is suffering from both male's oppression and mistreating and the patriarch government at the same time. In spite of the fact, that patriarchy is a system that treated women as inferior in all aspects of life and experience all kinds of oppression, exploitation, and subordination by men (Bhasin, 2006). By taking a closer look, at how Orwell depicted Winston in the novel, one can see how he is persecuted by a system that 
society supports him. Owing to his work in the Ministry of Truth, his rebellious nature and his urge to live without any limitations, like "most men in this... [patriarch] nation, feel troubled about the nature of their identity" (Hooks, 2000), he becomes obsessed with his past. However, as a result of the dominating repression, he tries hard to dissemble his "true self", from the thought police. The thoughtcrime he commits is purchasing a dairy to write his thoughts in old speak, not in the official language of the state, Newspeak. $\mathrm{He}$ is actually aware of the fact that one day he will be arrested and punished for the "thought crime" that he has been committing for a while. So as not be disconnected with his personal history, he dares to "open a diary... [That] was not illegal (nothing was illegal since there were no longer any laws), but if detected it was reasonably certain that it would be punished by death, or at least by twenty-five years in a forced labor camp" (Orwell 8). This had led to a bold statement of proposing that the male political subject is actually female over the collectivity; the state tyrannized Winston in the same way he does with Julia; in other words, men are oppressed in the public sphere exactly like women do in the private sphere.

When talking about feminist criticism from this time was obviously tied to raising consciousness about centric society in which women felt trapped. The woman is stripped of her intellectual and physical freedom. They are unable to make creative nor rational choices for themselves. The male-centric persecution of the woman is so physically and mentally restricting that it ultimately makes her crazy, liberating her from the control of her husband and society... But they ignore the fact that "... yet the poor or working-class men who have been socialized via sexist ideology to believe that there are privileges and powers should possess solely because he is male often finds that few if any of these benefits are automatically bestowed him in life" (Hooks,2000). Winston who presents working-class men in society is also suffered from patriarchal oppression and prohibited from writing his dairies by Big-Brother, the patriarchal figure in the novel. Patriarchy can indicate to a particular society where the father (the patriarch), ruled not only women in the family but also the young men. It is the case of the Oceania society, it is a patriarchal society, in which Big- Brother controlled not only Julia but Winston as well.

Patriarchy theory goes beyond claims of discrimination, and formulates as follows: Men hold power in society, to the benefit of other men, to the detriment of women. The result of which is that women as a group, are being oppressed by men as a group. As a result of this oppressive attitude against women, the feminist activist started to discuss the manner by which patriarchy was destructive to men, without changing their furious critique of male domination politics extended to incorporate the acknowledgment that patriarchy stripped men of specific rights, forcing on them a sexist masculine identity (Ibid). It is true that the power in Oceania society is in the hand of men, like any patriarchal society, in which the system of any association ( political, financial, economic, social or religious ) is overwhelmed by a number of upper status in hierarchies that occupied by men (Goldberg, 1979). The female politicians are usually a lower proportion than males. But patriarchy is also harmful and oppressive to men in a certain way (Hooks, 2000). Oceania's state administration create masses among which individually do not have the chance to realize themselves.

Winston by writing his dairies aims to lead a life out of conversations imposed by the system, which devastates him both physically and psychologically. It is important throughout the kind of relation between Smith and the Ocean's state to recognize that patriarchy intends to define hierarchal relations, these hierarchical relations can be noticed between the government and citizen (Sharabi, 1988). The state's political order that is foregrounded in the novel is totalitarianism, the oppressive system that serves the interests of the rulers. Ardent describes the totalitarian movement as the demand of the regimes "for total", unrestricted, unconditional, and unalterable loyalty of the individual member", ensured by a system of control and punishment. The totalitarian state is a state in which the only power holder, who endeavors to control virtually all aspects of life, comprising the science, economy, art, education, private life and ethics of citizens; all members of citizens without exemptions, male and female (1973).

Most of the feminist researchers argue that masculinity and misogyny subjects can be seen through most of his works. They considered him as an anti-feminist, and moreover, they accuse him that he is a women hater. Because of his decrying and scoring standpoints towards women through his female characters. (Eckstein, 1984; Voorhees, 2009). From a feminist point of view, it is accord with that in 1984 the female characters are seen from a male- cantered perspective and therefore presented primarily in their biological, primordial role (Patai, 1984; Whitney, 2011). It seems that Patai and Whitney, are believing in Wallaby's definition of patriarchy, that women are characterized as victims of a system. This system involves the state. It implies that women have constrained agency ( Walby, 1990). This is debatable; first, as Oceania is a totalitarian state, one must ask are men in this state not oppressed? Is Julia the only oppressed citizen by BigBrother? Is Winston have more rights and privileges than Julia in the state? We cannot simply argue that Julia is the 
only victim of patriarchy in the novel, but Winston too, is not able even to write his diaries in the language he wants - old speak- but he is considered guilty only because he uses it. It is significant to note that "it is Julia who initiates the relationship [with Winston], it is she who confidently and with practiced ease breaks a capital law by declaring her love for him, while he is considering ways to murder her for fear, she is a member of the thought police"(Newsinger, 1992). For this reason, I integrate this understanding introduced by Wallaby, as well as, Patai and Whitney's results of analyzing female characters of 1984 , and accusing George Orwell that he is anti-feminist, because both the definition of Wallaby and the examination of female characters of the novel, neglected the subjection of men by other men in any patriarchal society. In the case of the protagonist of 1984 -Winston- it is can be said that at times, and in specific situations, men are feminine, with their social and political identity. Feminist activists operate the feminist movement on the accurate same oppressive systems they aim to abolish men into one classification (Akgul, 2017). This class expects that all men profit from patriarchal sexism and that men are constantly the oppressor. But in reality and in the case of Winston, it is not. The persecution of the same men originates from other men who are more privileged than them. Winston in the novel is suffering from the oppression of Big-Brother, who is a man like him, but he is occupying a higher position in the government.

\section{CONCLUSION}

In the end, we can say that the patriarch Big-Brother in the novel, is given the authority and power within Ocean's society, in order to exercise his authority over the citizens. So the social surveillance in Oceania is constrained by the male not female ruler. Owing to the fact that women are purposely eliminated from what is regarded as neutral by patriarchal agents. However, this neutrality has confirmed to be men oriented. Thus, patriarchal dictatorship demonstrated itself over exclusion and inclusion mechanisms, on issues that are urgent to the female subject and in contrast, if not apposition to her position within a particular socio-economic structure. We cannot deny that the main objects of the state are women. But it is important to note that men as well are mistreated and subordinated by the Oceania state. Julia and Winston are indeed oppressed by the man Big-Brother, which leaves no questions if men are also oppressed or only women who are oppressed in a society in which the power in the hands of men?. From this perspective, it could be agreed that the relation among the citizen and the government in the public sphere is equally patriarchal to the relation among men and women in the private sphere. The paper's hypothesis supports this perspective, as it agreed that the male political subject is subjugated to the government in the same manner women are subjugated to men.

\section{REFERENCES}

[1] Akgul, F. (2017). Patriarchal Theory Reconsidered: Torture and Gender-Based Violence in Turkey. Springer.

[2] Arendt, H. (1973). The origins of totalitarianism (Vol. 348). Houghton Mifflin Harcourt.

[3] Atwood, M. (2004). The Handmaid's Tale and Oryx and Crake "In Context." Pmla, 119(3), 513-517. https://doi.org/10.2307/25486066

[4] Bhasin, kamla. (2006). what is patriarchy:women unlimited. In New delhi

[5] Crick, B. (2007). Nineteen Eighty-Four: context and controversy. In A. John Rodden, University of Texas (Ed.), The Cambridge Companion to George Orwell (pp. 146159). Cambridge University Press. Retrieved from https://doi.org/10.1017/CCOL0521858429.012

[6] Goldberg, S. (1979). Male dominance: the inevitability of patriarchy. Sphere.

[7] Hooks, B. (2000). Feminist Theory: From Margin to Center. Boston: South End Press. Retrieved from https://books.google.com/books?hl=en\&lr=\&id=uvIQbop4c dsC\&pgis=1\%5Cnhttp://books.google.com/books?id=uvIQb op4cdsC\&pgis $=1$

[8] Morrissey, S. (2003). Patriarchy on trial: suicide, discipline, and governance in Imperial Russia. The Journal of Modern History, 75(1), 23-58.

[9] Newsinger, J. (1992). \{INineteen Eighty-Four\} Since the Collapse of Communism. (E. James, Ed.), Foundation (Vol. 56). Foundation, The Science Fiction.

[10] Patai, D. (1984). The Orwell mystique: a study in male ideology. Univ of Massachusetts Press. Retrieved from http://books.google.com/books?hl=en\&lr=\&id=ggyr7ddFYUC\&pgis $=1$

[11] Seaton, J. (2010). John Rodden, ed. The Cambridge Companion to George Orwell. Society, 47(2), 160-163. https://doi.org/10.1007/s12115-009-9291-9

[12] Sharabi, H. (1988). Neopatriarchy: A theory of distorted change in Arab society. Oxford University Press, USA.

[13] Sylvia Walby. (1990). Theorizing Patriarchy. oxford:blackwell.

[14] Whitney, L. (2020). Depth of the Feminine Character: An Analysis of Julia and Offred. Retrieved from https://www.academia.edu/1281290/Depth_of_the_Feminine _Character_An_Analysis_of_Julia_and_Offred 